\title{
O PONTAL DO ESTALEIRO: ESTUDO ETNOGRÁFICO DA MEMÓRIA DO TRABALHO NA CIDADE DE PORTO ALEGRE, RS
}

\author{
Ana Paula Marcante Soares ${ }^{1}$
}

\section{Introdução}

A orla da cidade de Porto Alegre, às margens do 'Rio' Guaíba, está em transformação. A região que envolve o bairro Cristal, mas não se define pelos seus limites, estendendo-se à 'orla sul' e à orla norte' do Guaíba está inserida no contexto mais amplo de projetos urbanísticos que visam intervenções ao longo da Orla, especialmente no Cais do Porto e na zona sul da cidade. Os moradores dessa região experenciam, nos últimos anos, a remoção de 'vilas', a construção de um 'hipermercado', a construção de um shopping alçado ao maior da America Latina, a construção de um museu de arte contemporânea.

Paralelo às edificações e remoções para viabilizá-las nos espaços antes ocupados pelas diversas vilas que (ainda) compõem o Cristal, há a implementação do Projeto Integrado Socioambiental- PISA da Prefeitura Municipal que tem como principal objetivo ampliar a capacidade de tratamento de esgotos da Capital buscando, assim, futuramente, a balneabilidade das águas do Guaíba. Mais recentemente, ocorrem os conflitos envolvendo as obras de infraestrutura urbana em razão da Copa do Mundo de futebol, em 2014, além das disputas em torno da extensa área do antigo Jockei Clube da cidade.

Nesse contexto, em meio às contradições da lógica desordenada das 'vilas' que ocupam essa região da cidade e dos prédios e das casas que habitam camadas médias urbanas, esses habitantes são provocados a moverem-se na dinâmica dessas 'formas' da vida social, experienciando mudanças de casas, trajetos, laços de vizinhança, práticas de trabalho e de sociabilidade, aderindo, ou não, à nova paisagem urbana que se desenha.

A vida social urbana é tema de estudos em suas formas (Eckert; Rocha, 2010: 87). Os processos de transformação urbana da orla do Guaíba e as intervenções formais enquanto objeto de políticas urbanísticas na cidade de Porto Alegre podem ser pensados pela via da sobreposição da cultura objetiva sobre a cultura subjetiva em Simmel (2004). A contradição simmeliana (Simmel, 2004) do fluxo que opõe a multiplicação contínua de formas de socialização novas, construídas na interação dos indivíduos entre

\footnotetext{
${ }^{1}$ Universidade Federal do Rio Grande do Sul, Brasil.
} 
si, e as formas fixas, expressas num processo de objetivação cujos projetos urbanísticos para Orla, aqui, poderiam representá-las.

Trata-se de pensar aqui quais as dimensões simbólicas que esse território, objeto dessas intervenções urbanas, evoca para os habitantes de Porto Alegre, especialmente dessa região da cidade. É sobre a rítmica e a ressonância do fluxo dessas significativas transformações urbanas nas suas relações com práticas de trabalho operário nessa região, em Porto Alegre, RS, que proponho refletir nesse trabalho. Proponho pensar as continuidades e descontinuidades do tempo vivido da experiência de trabalho (Eckert, 1993) de construção naval tida como singular no contexto urbano porto-alegrense, na área conhecida como 'Pontal do Estaleiro', às margens do Guaíba, no bairro Cristal.

O espaço hoje destinado ao projeto 'Pontal do Estaleiro' cuja proposta de intervenção urbanística propõe um grande empreendimento imobiliário esteve, durante muitos anos, associado ao trabalho operário na área de construção naval. O Estaleiro Só iniciou suas operações há mais de cem anos na cidade de Porto Alegre, inicialmente na Rua Voluntários da Pátria, área central e fabril da cidade, sendo transferido, em meados da década de 50, para o Cristal em razão da obras de ampliação do Cais do Porto, permanecendo lá até o encerramento, em definitivo, das suas atividades na década de 90.

Ancorada em minhas experiências de campo ${ }^{2}$ no bairro e para além de suas 'fronteiras', em Porto Alegre, para condução da pesquisa de doutoramento, trago as narrativas biográficas (Eckert, 1996) de antigos ex-trabalhadores do Estaleiro Só, refletindo acerca de suas trajetórias de trabalho e as dimensões simbólicas e materiais evocadas por eles e as relações com o processo de transformação urbana da Orla do Guaíba, em Porto Alegre.

Para fins da reflexão proposta, inicio com o que denomino de 'tempo de trabalho' no qual apresento a experiência de trabalho operário desses trabalhadores nas tensões da complexidade do cotidiano do trabalho de construção naval, envolvendo os desafios de qualificação profissional e usos da tecnologia própria da época. São essas narrativas que tecem o percurso de descoberta do 'Pontal do Estaleiro' como espaço de trabalho operário na cidade.

\footnotetext{
${ }^{2} \mathrm{O}$ trabalho de campo de forma intensiva fora realizado desde agosto de 2011 para fins do Projeto de Tese desenvolvido junto ao PPGAS/UFRGS e Banco de Imagens e Efeitos Visuais/UFRGS.
} 
Sugiro problematizar algumas questões envolvendo a conformação e transformação do Pontal e da região onde se insere a partir de relações entre a morada dessa comunidade de trabalho com suas práticas de trabalho operário no Estaleiro Só.

Num segundo momento, proponho refletir o que denomino de 'tempo de crise', a partir das suas experiências individuais de saída do Estaleiro inseridas no contexto mais amplo do fenômeno de crise do setor naval brasileiro e seus reflexos para essa atividade na cidade de Porto Alegre e as intervenções urbanas que se seguiram ao encerramento de suas atividades.

É na sobreposição e conexão dessas temporalidades diferencialmente experenciadas pelos antigos trabalhadores da construção naval narradas por eles que nos são reveladas questões significativas para pensar o tempo vivido dessa comunidade de trabalho e sua relação espaço-temporal com a conformação e dinâmica de transformação do Cristal, da Orla e da cidade.

\title{
O Pontal do Estaleiro: tempo de trabalho
}

Ao ler atentamente a capa de um jornal de circulação interna do Estaleiro Só que trazia a imagem de um imponente navio batizado como "Aurora", atento ao modo de retratar o período tido como 'auge' da construção naval, no país, durante a década de 70. O mais curioso, contudo, foi observar, com certa estranheza, que o navio ali era tratado como um sujeito, simbolicamente, 'batizado',

\begin{abstract}
Mostra a graça e a beleza de tuas linhas. Foste trabalhado com muito amor, durante meses, para receberes hoje o batismo nas águas do Guaíba. Centenas de pessoas se esforçaram para te dar este porte altivo. És o símbolo de uma empresa que já tem o seu valor reconhecido no exterior, através de outros navios como tu, feitos para exportação. Na casa onde nasceste, continuaremos acumulando trabalho e tecnologia para fazer da construção naval mais uma riqueza do Rio Grande. Breve, nosso Estado será percorrido, de ponta a ponta, via fluvial. [...] Portanto, abre teu caminho, Aurora, e vai contar ao mundo estas boas novas. (SÓ Notícias, 1976)
\end{abstract}

Na década de 60, a indústria da construção naval brasileira passou por uma grande expansão, quantificada no significativo aumento de mão-de-obra do setor e das contratações e, nos anos 70, o Brasil alcança a posição de segundo maior parque naval mundial, atrás apenas do japonês (Jesus; Gitahy, 2009). A expansão da indústria naval fora fomentada por algumas políticas governamentais específicas de desenvolvimento do setor que envolviam, entre outras ações, a aprovação de projetos para modernização 
e expansão de Estaleiros e a fixação de reciprocidade no tráfego marítimo (Jesus; Gitahy, 2009: 3902).

No contexto Riograndense, desde 1959, o Grupo Executivo da Indústria da Construção Naval, órgão governamental de gestão do setor, responsável à época, aprovara o Estaleiro Só como o único estaleiro de construção naval fora dos Estados da Guanabara e do Rio de Janeiro. ${ }^{3}$

Para além dessas representações sobre o trabalho naval em suas lógicas e feitos externos representados nesta matéria de capa, antes citada, são as memórias ritmadas em temporalidades descontínuas dos antigos trabalhadores do Estaleiro e suas interpretações que revelam sua própria experiência de sujeito da memória (Eckert; Rocha, 2010: 85). Revelam o "como" das práticas de trabalho operário e o "por quê" das lembranças afetivas desse tempo que lá trabalharam.

A cerimônia de lançamento de um navio era momento de festa no Estaleiro e repleto de honrarias e formalidades: palanque montado, muitos convidados, discurso de autoridades, batismo pela Madrinha, quebra da garrafa de champagne no casco e lançamento do navio nas águas do Guaíba. Seu Manoel, um velho soldador aposentado, inicia sua trajetória de trabalho, no Estaleiro Só, no final da década de 50 e fala dessa dimensão simbólica do 'se despedir' do navio como 'sujeito' construído afetivamente no saber fazer de sua prática.

[...] O 'Neide' então, não sei se foi segundo ou terceiro que nós fizemo... [...] Esse navio, quando foi botado pra água, o primeiro que nós fizemo, 'Alcotur' era o nome dele. Ai depois parece que mudaram o nome dele para 'Celina Ramos' parece, aquele também a gente chorou quando botou pra água, trabalhava não sei quanto tempo nele ali né? De repente se vai embora pra água, coisa de louco, bonito aquilo ali.

A representação desse trabalho operário da construção naval envolve a atribuição ao seu desempenho de qualidades comuns próprias de prática de trabalho tida como singular seja pela dimensão física dos navios e sua matéria-prima básica, o aço, seja pelo enfrentamento de situações de risco que esta dimensão impõe, conformando as noções de conhecimento para a prática de trabalho e de aprendizado para adquiri-lo.

\footnotetext{
3 O Rio de Janeiro considerado, à época, como ainda o é, pólo naval, no país. In: Livro de fotos comemorativo do Estaleiro Só S.A, trazendo suas realizações desde 1964. [Sem indicação de ano de publicação].
} 
Por que assim que entrei no Estaleiro, em 57, eu não sabia fazer nada, ai pintar o navio de trincha eu pegava o pincel com as duas mão, assim ó. [...] Ai foi indo, foi indo, fui aprender a soldar, ai passei pra caldeiraria. Mas, eu cheguei lá não sabia nada, nada. [...] Então, dai foi indo, foi indo. Até um dia que eu disse assim, 'seguinte não to levando, não to aprendendo nada, queria aprender'. [...] Ai na outra semana quando tava seu Almero que era Mestre Geral pra passar pra caldeiraria, ai caldeiraria é maçarico, é máquina de solda, ai passei pra calderaria e pronto não sai mais. Passei pra soldar, soldar e ai não fiz mais nada. Fiquei só na solda. [...] A maioria aprendeu lá, tudo aprendeu. [...] A não ser os engenheiro que vinham de fora, se formava. Mas, a maioria tudo arigó né, tudo arigó, aprendeu dentro lá.

(Seu Manoel, aposentado, ex-funcionário do Estaleiro Só)

As noções de conhecimento e aprendizado, para o caso das práticas de trabalho operário naval, se operavam na experiência de trabalho dos próprios operários que passavam a atuar como 'formadores' de uma mão-de-obra cuja prescindibilidade de especialização adequada prévia às contratações se justificava pela ausência, no mercado de trabalho, à época, de 'especialistas'.

Tu sabe que nós lá, o Estaleiro foi uma escola. Não sei se já te falaram isso ai. A gente treinava o pessoal, a gente formava o pessoal em, como é que se diz... em calderaria, em elétrica, mecânica, tudo. E cada setor, aquele que tinha mais experiência, no caso eu, o Albino, o Cláudio Prolicárpio... [...] Saia com diploma e tudo. [...] o Estaleiro que abriu este caminho, para a gente ensinar o pessoal, então a gente teve aulas no SENAI... para poder ensinar, eles orientando a gente para orientar como é que a gente tinha que trabalhar com o pessoal. Por que tu sabe né, pegar um pessoal analfabeto para trabalhar é brabo né? Barbaridade.

(Seu Fernando, aposentado, ex-funcionário do Estaleiro Só)

Durante a fala desses antigos trabalhadores, operários da construção naval, percebo o prazer que tinham em me explicar e esmiuçar cada detalhe técnico de sua atividade e não somente por que, de forma geral, são técnicas de precisão, mas como forma de revelar as suas memórias afetivas de uma trajetória de trabalho. Iniciando uma narrativa sobre o tempo em que trabalhava no Estaleiro, Seu Manoel me diz orgulhoso

[...] Eu me lembro de tudo, tudo... eu tenho uma medalha de honra ao mérito comigo ai. Foi o primeiro soldador que deu o primeiro ponto de solda no primeiro navio. Ta guardado ai, minha medalha. [...]

(Seu Manoel)

Ao observar a planta fabril do Estaleiro conformada pelo "píer de acabamento", "cais de construção", "sala de risco", "carreira de lançamento", entre outros, descubro a existência, espacialmente diferenciada, de operários trabalhando em 'fases' e funções distintas do processo produtivo de fabricação dos navios. Essas fases do processo produtivo demarcadas por setores espacial e funcionalmente diferenciados são trazidas 
por Seu Manoel não somente como fundamentais à pratica singular de trabalho como uma melhoria conquistada ao longo de sua trajetória de trabalho no Estaleiro.

[...] a tal de praça de máquina do Estaleiro é uma chapa que vai aqui e aqui, tu vem pra aqui, tu vem pra ali, tu vai longe. Então, eu ia daqui pra lá soldando, lá eu me virava e vinha de lá pra cá por que não podia soldar o outro lado... [...] Então daí eles começaram a fazer o navio por parte, ai fazia um pedaço, ai ficou tudo mais fácil pra trabalhar, individual. [...] Então, por exemplo, você era um caldeireiro, de primeira, trabalhava com oito, dez arigó só pra fazer aquela parte ali, o outro fazia aquela parte ali, dai o negócio era tudo individual, cada um tinha sua turma, tudo certinho pra fazer aquilo ali. Então, eu era a parte da solda. Eu era soldador. Ai a minha vida continuou.

(Seu Manoel)

Essas diferenciações espaciais e essa temporalidade própria da construção naval estão presentes nas narrativas dos ex-trabalhadores do Estaleiro que, ao mesmo tempo em que fazem alusão a esse tempo longo de dedicação de força de trabalho a um 'produto' (a embarcação), por outro lado, destacam diferenças fundamentais para demarcação de lugares hierarquicamente distintos no processo de trabalho naval.

Ao tentar compreender a fala dos antigos operários sobre seu lugar no processo de trabalho no Estaleiro percebemos que essas diferenciações espaciais e temporais são insuficientes para uma caracterização da sua diferenciação interna (Leite Lopes, 1978). As narrativas dos antigos ex-funcionários, ao relatar a organização do trabalho industrial naval, com sua divisão de trabalho interna, nos diferentes 'setores' (espacialmente demarcados), revela a hierarquização das funções operárias do próprio Estaleiro.

Nas entrevistas, revelam-se essas diferenciações internas entre os operários pela sua autoclassificação com relação a sua função em um sentido mais restrito, como soldador, por exemplo, tida como profissão. Essa localização precisa no processo de trabalho, contudo, é sempre distinguida pela classificação (ou autoclassificação, como no caso de Seu Manoel) de quem era ou não genericamente categorizado como "arigó" ou "peão" cuja importância social em termos de capital intelectual e material (salário) era diminuta em relação às demais.

Este aspecto foi fundamental para pensar a trajetória de trabalho desses antigos trabalhadores do Estaleiro e seu reflexo em aspectos importantes para as questões aqui propostas, como as condições de vida enquanto moradores da região do Cristal, conforme se depreenderá ao longo do trabalho.

Sob essa perspectiva, essas diferenciações internas entre os operários dentro do Estaleiro revelam trajetórias profissionais e de ascensão enquanto projeto individual 
(Velho, 2004) diferencialmente experienciadas pelos entrevistados, como para Seu Fernando que começa como "peão" e ascende à "supervisor", estando abaixo somente das funções de chefia e gerência exercida por engenheiros.

Plano de Carreira né, eu trabalhei os 25 anos que estive lá, ou quase 30 anos, meu setor era esse ai. Eu recebia bloco por bloco, ia montando um com outro alinhando, entregando pra solda aquela coisa toda, até esse dia de lançamento ai. [...] Nessa época quando eu entrei, eu era peão, trabalhava como empregado normal. Ai três quatro meses eu já passei pra encarregado, ai foi ligeirinho, passei pra mestre, passei pra supervisor, ai...

(Seu Fernando)

As trajetórias de trabalho diferencialmente experienciada por esses homens, em termos de ascensão profissional, eram determinadas, por um lado, não somente, mas principalmente, pela educação, basicamente ser ou não alfabetizado, na medida em que não havia formação intelectual dessa massa de trabalhadores. Por outro, a experiência anterior em ofícios tradicionais poderiam ser capitalizadas em conhecimento para os cursos de formação e cargos de chefia, como no caso de seu Fernando. Ele trabalhara dez anos como serralheiro antes de ingressar num Estaleiro no Rio de janeiro, determinantes para seu ingresso e ascensão no Só.

Pude observar, ainda, a divisão etária do trabalho no interior de uma divisão técnica na qual são revelados laços geracionais entre os mais antigos e experientes e os mais novos e inexperientes à época. Os mais 'velhos' e experientes que detinham o conhecimento prático e tradição de um saber fazer ensinavam os mais jovens, muitos engenheiros, que detinham o capital intelectual, vindo a ocupar as posições de chefia.

Pegavam uma turma de estagiário que estavam saindo da faculdade, chegava lá entregava pra mim e entregaram um bando dessa gurizada.... [...] Ai deram pra mim. Ai eu perguntei 'o que vocês querem?' 'nós queremos aprender', 'mas aprender o quê?', 'vão meter a mão na ferramenta?'. Sim, pra aprender tem que ser assim né, não ficar sentado, faz isso, faz aquilo. Ai eles toparam. Ai fui lá dei ferramenta para todos eles, 'vamos trabalhar'. Botei eles de ajudante. Ai eles começaram a trabalhar, a fazer o serviço também. Esse ai começou assim, o Dirceu. Depois, ele foi meu chefe no Estaleiro. Por que ele se formou, estudou, aquela coisa toda e foi meu chefe nesta área de construção naval. [...] Se formou engenheiro.

A indústria naval, comparada a outros setores industriais apresenta especificidades importantes, tais como capital e mão-de-obra intensivas, daí a presença de centenas à milhares de trabalhadores envolvidos diretamente no processo produtivo de construção e reparação das embarcações, dentro do Estaleiro. Aspecto este recorrente na fala dos ex-trabalhadores que entrevistei. 
Caracteriza-se, ainda, pela fabricação de bem de capital de alto valor unitário e pela inconstância no seu nível de atividade uma vez que trabalha por contratação de obras sob encomenda e de longo prazo de maturação (Jesus; Gitahy, 2009: 3912). A construção de um navio de grande porte leva em torno de dois anos e mobiliza um grande aporte de capital e trabalho.

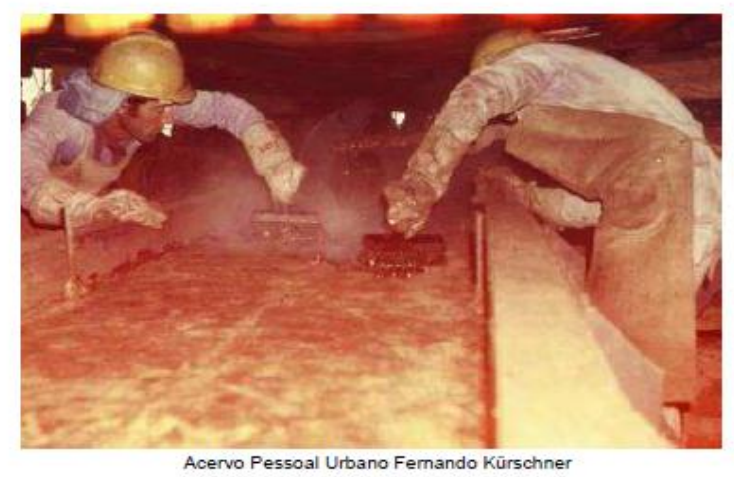

Acervo Pessoal Urbano Fernando Kürschner

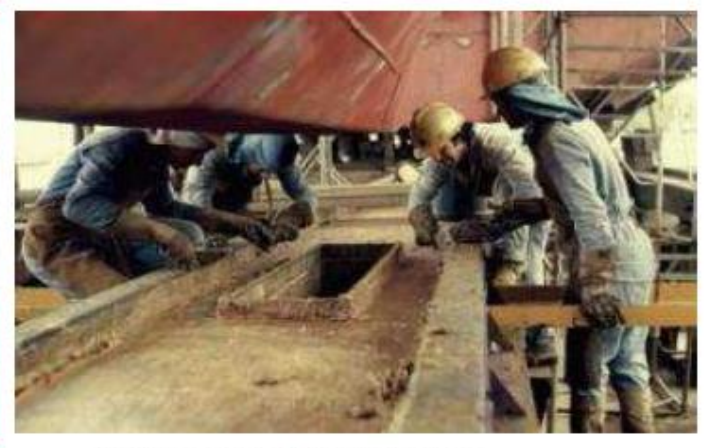

Acervo Pessoal Urbano Fernando Kürschner

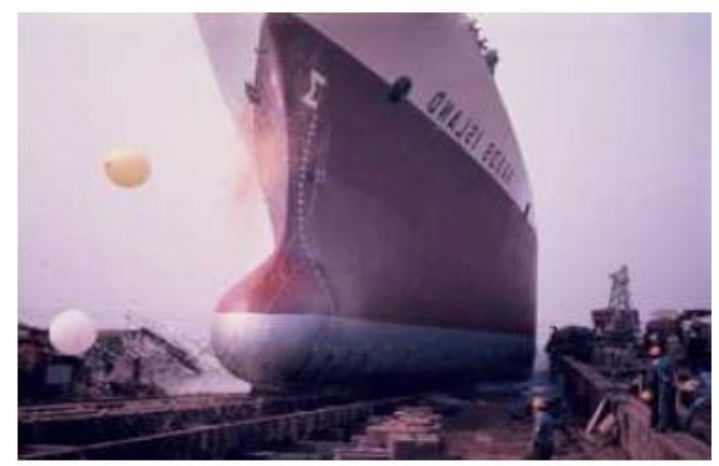

Acervo Pessoal Urbano Fernando Kürschner

As entrevistas ${ }^{4}$ com os antigos trabalhadores do Estaleiro Só revelam o detalhar, com precisão, das técnicas que envolviam a prática do trabalho no Estaleiro, a dinâmica

\footnotetext{
${ }^{4}$ As entrevistas citadas no trabalho se deram com ex-trabalhadores do Estaleiro Só e foram realizadas, individualmente, em mais de uma oportunidade com cada um deles, com quatro antigos trabalhadores. Hoje eles estão aposentados e, ao longo dos mais de 25 anos trabalhados no Estaleiro, exerciam funções técnicas distintas do processo de construção naval. Outras entrevistas foram realizadas com um grupo de quatro engenheiros que ainda trabalham, alguns em atividades diversas, outros permaneceram em atividades indiretamente relacionadas à reparação naval. Essas últimas não são citadas diretamente no trabalho.
} 
do seu funcionamento, o cotidiano operário, os laços de trabalho, práticas e saberes, tecendo a descoberta de um 'lugar' de trabalho no Pontal e naquela região da Orla ${ }^{5}$.

\section{O trabalho e a morada}

$\mathrm{Na}$ fala dos entrevistados que moravam mais próximo ao Pontal era recorrente a lembrança dos ruídos do Estaleiro. A dimensão dos equipamentos e aço manuseados durante o processo de construção naval permitia a ele ouvirem o Estaleiro operando, mesmo enquanto descansavam em suas casas.

Aqui a gente estava aqui sentia o barulho da marreta, lá no navio, dava pra ouvir o barulho do pessoal trabalhando .... Tu vê?

(Seu Paulino)

O aporte de trabalho mobilizou uma grande massa de trabalhadores no Estaleiro Só que, no 'auge' da produção naval, ao longo da década de 70 , contava com mais de três mil trabalhadores, revezando-se em três turnos, manhã, tarde e noite. O fluxo descontínuo de capital determinado pelas entradas de novas encomendas de navio poderia repercutir diretamente em ganhos materiais a alguns dos trabalhadores assalariados.

O valor trabalho é assim acionado para legitimar a dedicação desses homens ao trabalho naval, muitas vezes para além das oito horas legais de trabalho diárias remuneradas. O morar perto do local de trabalho era evocado como aspecto que facilitaria essa dedicação às inúmeras horas extras de trabalho. Freqüentes eram os relatos de chamadas noturnas de urgência às situações de dias 'a fio' trabalhando para cumprimento de prazos.

[...] Foi diariamente pra soldar uma caldeira que andou arrebentando não sei o que lá, eu botei duas máquinas de solda pra poder concertar aquela caldeira pro pessoal ter água quente no navio, se não eles não tinham. Ai eu trabalhei dia e noite. Até que foi lá que eu ganhei um cheque da empresa que deu pra comprar esse terreninho aqui... é comprei, tenho amor a isso aqui por que foi suado, foi suado... Então, eu dei a entrada, comprei um terreninho, fiz uma casinha, uma maloquinha, foi indo né tchê... e ai fiz essa casinha.... [...] Então, assim foi minha vida, trabalhando, fazendo a vida...

(Seu Manoel)

\footnotetext{
5 Embora não se adentre na questão de gênero do trabalho naval praticamente restrito ao universo masculino, também entrevistei mulheres que trabalharam em funções administrativas e de assistência aos funcionários, no Estaleiro, e que contribuíram para a descoberta desta memória do trabalho naval na cidade.
} 
Nos relatos dos entrevistados, a insuficiência do ganho para alguns, o risco da atividade para todos seriam compensados pela importância que sugerem ter o caráter seguro e estável do seu emprego (Leite Lopes, 1978) para si e sua família e pelos 'prêmios' recebidos e reificados na conquista de patrimônio pessoal.

Esses barcos aqui quando o Estaleiro assinou o contrato, ai eu disse para minha veia, agora dá para gente trocar de carro. Eu tinha um fusquinha, ai nós compremo a camionete. A camionete está com trinta e cinco anos.... para ver como é que é as coisas...

(Seu Fernando)

Os trabalhadores do Estaleiro Só moravam, em sua maioria, no bairro Cristal, nas proximidades do 'Pontal do Estaleiro' onde se localizava o espaço fabril. Dos antigos operários do Estaleiro que entrevistei todos moravam no bairro ou em bairros limítrofes, como no Camaquã, por exemplo, onde ainda mora Seu Fernando. Adquiriram suas moradas ao longo da sua trajetória de trabalho no Só, residindo junto com suas famílias até hoje, há mais de quarenta anos.

Como moradores dessa região da cidade de Porto Alegre acompanharam e experienciaram as transformações urbanas que lá ocorreram. Nas narrativas dos antigos trabalhadores do Estaleiro, a lógica do salário certo e constante é associada à possibilidade deste operário obter a sua casa própria. Diferentemente de outros contextos empíricos (Leite Lopes, 1978; Eckert, 1993) dedicados ao estudo do mundo do trabalho, não há mobilização da mão-de-obra operária através da concessão de moradia por parte do Estaleiro a seus trabalhadores.

São as políticas governamentais de incentivo ao financiamento habitacional ${ }^{6}$ para classes trabalhadoras urbanas e camadas médias, à época, que determinaram a possibilidade de trabalhadores adquirirem as suas moradas próximo do Estaleiro Só. A região e, especialmente, o bairro são marcados pela presença de vastos conjuntos habitacionais, assim como o apartamento simples e confortável onde reside Seu Paulino e outros ex-funcionários do Estaleiro.

\footnotetext{
${ }^{6}$ No início dos anos 60, ocorre o marco, em termos de intervenção estatal mais incisiva na provisão de habitação, no Brasil, representado pela criação do Sistema Financeiro da Habitação, o Banco Nacional da Habitação (BNH), sociedades de crédito imobiliário, letras imobiliárias, e o Serviço Federal de Habitação e Urbanismo. PLANHAB, Plano Nacional de Habitação, 2006. Disponível em: www.cidades.gov.br.
} 
A maioria trabalhava ali no Estaleiro, a maioria daqui do pessoal que morava aqui trabalhava no Estaleiro, muita gente daqui dos blocos trabalhava ali por que isso era uma cooperativa na época dos funcionários públicos do Estado. E muita gente entrou nesse esquema, 'ah, moro ali'.

(Seu Paulino)

A paisagem urbana do bairro se conforma pela conjugação do espaço fabril e de morada da grande maioria dos operários que lá trabalhavam. As narrativas sugerem que é a expansão da massa de trabalhadores ao número de milhares que acarreta a significativa ampliação de uma mão-de-obra que residia em outras regiões da cidade e na região metropolitana. Mas, ainda assim, grande parte dos trabalhadores moravam no bairro Cristal.

Ainda que consideremos toda a complexidade da questão de classes inserida no fenômeno mais amplo de urbanização na qual são tencionadas relações de produção, especialização ocupacional, estratificação de renda e as diferenças de status e de prestígio social, uma das expressões mais evidentes dessa diversidade sociocultural repleta de contrastes é a hierarquização estabelecida através do modo de morar e a distribuição por bairros nas cidades (Velho, 2007: 12).

Nesse sentido, a paisagem urbana da região em torno do Cristal é ainda hoje marcada por esses contrastes: as 'vilas' em visíveis condições de pobreza e precariedade concentradas em espaços entre os blocos habitacionais e as amplas casas e prédios de camadas médias urbanas.

Essa configuração, por sua vez, remonta à própria conformação de um espaço fabril cuja ocupação dos vazios urbanos no em torno do Estaleiro deram início a formação do processo de 'perifização'. Inserido em processos sociais mais amplos e complexos de desigualdade e segregação espacial da cidade (Caldeira, 2000), as ocupações 'irregulares' foram iniciadas com o Estaleiro Só e ampliadas com a construção do Hipódromo Cristal localizado próximo ao espaço da 'fábrica' (Porto Alegre, 2003). Para aqueles operários em condições de pobreza a ocupação dos vazios próximos ao espaço fabril era 'naturalizado' pelos entrevistados. Ao lado do Estaleiro, existia, na época, uma vila que é recorrente nas narrativas desses ex-trabalhadores.

Esse pontal aqui tu conhece né? Aquela zona de baixo onde se vem de carro, ali teve duas vezes uma vila ali. Vila mesmo. Ali até para entrar, para tu passar era um problema. E foi indo, desmancharam para começar a fazer aquela estrada ali, ocuparam de novo. Ai desapropriaram para começar a estrada de novo, a outra mão ali. 
Até certa medida, a diferenciação interna da organização do trabalho naval, antes mencionada, colocou certos trabalhadores em uma posição diferencial, como, por exemplo, Seu Fernando e Seu Paulino, cujo reflexo em melhores condições de vida de uma classe operária poderiam ser atentadas pela forma de habitação, no contexto urbano do bairro Cristal.

É interessante pensar, por outro lado, que se propuséssemos um mapeamento das moradas desses antigos trabalhadores a partir da própria hierarquização do bairro, pelas suas formas de habitação, e pela hierarquização funcional deles no trabalho desempenhado no Estaleiro não necessariamente há uma correspondência.

Como moradores há mais de 40 anos dessa região da Orla de Porto Alegre, os depoimentos dos antigos trabalhadores do Estaleiro Só traziam o intenso processo de transformação da paisagem urbana dessa região da cidade, especialmente próximo a região do 'Pontal do Estaleiro'.

O crescimento da planta fabril do Estaleiro, a dinâmica de ocupação e desocupação da vila próxima, as mudanças de trajetos e construção de acessos eram as mudanças recorrentes nas memórias desses trabalhadores.

A própria atividade naval acompanha esse processo de transformação da região próxima ao Pontal. O cotidiano do trabalho industrial exercido em contextos urbanos tal como do Estaleiro envolvia os desafios dos usos da tecnologia adequada à ampliação de suas finalidades, abarcando a produção de embarcações que exigiam espaços e equipamentos de dimensões ainda maiores. Para isso os aterros eram freqüentes. Seu Paulino conta que para fazer o aterro para as ampliações do espaço fabril do Estaleiro buscaram a terra no morro Santa Tereza, na região ali próxima do Pontal.

E ali no Estaleiro, eu na época aterrei a metade do Estaleiro com o aterro daqui do Morro do Santa Tereza. Eu participei do trabalho por que eu que recebia os caminhão de aterro. O Estaleiro, [...] onde ta esta festa aqui, isso aqui era Guaíba, depois construíram isso aqui em cima do aterro. [...] Recebia a terra, tinha uma draga que tava dragando na época, era noite e dia, ela ia deixando e nós ia tocando água, tocando a terra em cima, isso ai foi afundado esse Guaíba.

(Seu Paulino) 


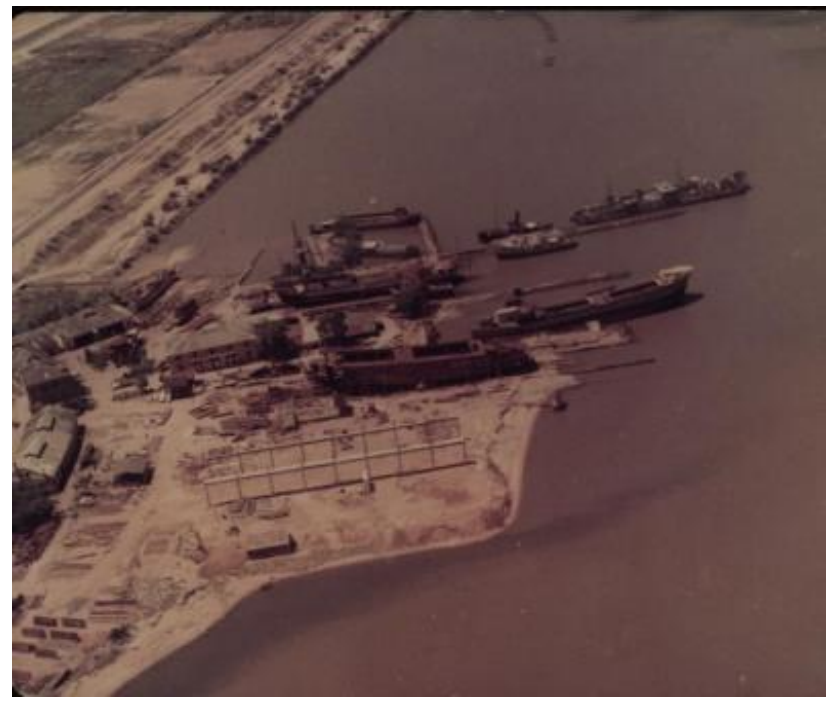

Acervo Pessoal Pedro Afonso Freitas

\section{O Pontal do Estaleiro: tempo de crise}

Foi interessante descobrir através das narrativas a noção do valor trabalho em cada experiência temporal desses antigos trabalhadores na dinamização da sua memória sobre um passado e um presente expressos numa relação temporal vivida diferencialmente por esses sujeitos com a prática de trabalho naval e com o espaço dessa prática, onde ainda residem.

Os antigos trabalhadores do Estaleiro Só narram sua trajetória de trabalho em temporalidades distintas. Revelam o esforço da produção de sentido da prática de trabalho naval em suas memórias ritmadas em temporalidades descontínuas, mas que num processo de reordenamento reconstituem o vivido num passado de um tempo de trabalho e de um tempo de crise. Esse tempo de crise está num presente marcado pela representação do fim de sua trajetória de trabalho e pelas ruínas do Estaleiro e seu desaparecimento. O fim das atividades do Estaleiro, com a falência na década de 90, encerra a atividade de construção naval na cidade de Porto Alegre.

As descontinuidades deste tempo de crise são reatualizadas pelos entrevistados diferencialmente em alguns aspectos, mas as referências estruturais são sempre 'a política' e o 'governo' como determinantes para o fim do Estaleiro Só. 
Ai eu fiquei esses 22 anos. Ai o nosso Diretor que foi o Cleber se meteu na política e.... depois vendeu certas ações da firma e relações, se meteu na política, parece que não chegou a ganhar, é não ganhou não. [...] Ai eles venderam ações do Estaleiro, 49 ações parece, por cento, que eles venderam para aquele Estaleiro Ebin do Rio. Ai o Ebin entrou ai e sei lá, começou o troço dá pra traz, dá pra traz, aqueles incêndio ali...

(Seu Manoel)

Ebin é que tomou conta. Isso ai é política. Tudo é política. Eles achavam que o Estaleiro aqui estava, não estava dando conta do recado, aquela coisa toda. Eu não sei por que também essa nova Diretoria que eles compraram, compraram? Deram pra eles. Eles compraram o maior número de ações né. Então, ficaram mandando. Ai trouxeram uma turma de lá.

(Seu Fernando)

[...] é uma vida ali né... era noite e dia. Aqui a gente estava aqui sentia o barulho da marreta, lá no navio, dava pra ouvir o barulho do pessoal trabalhando .... Tu vê? Acabaram com tudo. Tudo é coisa de política, acabaram com o Estaleiro, foi o político que tirou daqui e levou pro Rio. Lá no Rio, tinha uns três Estaleiros grande, era o Escavagima, esse ai o do Ebin, e tinha mais outro.... quebrou tudo.

(Seu Paulino)

Passada a euforia do 'auge' da indústria naval brasileira ao longo da década de 70, o cenário nacional muda. A partir dos anos 80 , a situação da indústria naval brasileira se altera e inicia a gradativa diminuição da produção nacional e internacional fomentada pelas crises internacionais do petróleo da década anterior aliada à concorrência dos estaleiros asiáticos com custos de produção subsidiados pelos seus governos (Jesus; Gitahy, 2009). Ao longo desse período, o setor apresentava grandes perdas que se agravaram na década de 90, em meio a ausência de políticas governamentais para o setor, quando os principais estaleiros do país tiveram suas atividades paralisadas $^{7}$ (Jesus; Gitahy, 2009), inclusive o Estaleiro Só.

A própria trajetória de trabalho dos entrevistados, ao se aposentarem, desenha contornos mais claros para a crise do Estaleiro Só. Seu Manoel aposenta-se por invalidez e recebe integralmente a indenização a que tinha direito, pois se dá anterior ao agravamento da crise. Seu Paulino 'cai fora' como diz, é dispensado com a entrada do grupo carioca que passa a gerir o Estaleiro e se aposenta por tempo de serviço. Seu Fernando se aposenta por tempo de serviço e tem garantida a integralidade do valor da aposentadoria cujo relato não a traz como o cumprimento de um direito trabalhista, mas o gozar de prestígio junto à empresa. Muitos, nessa época, não receberam as verbas rescisórias.

\footnotetext{
${ }^{7}$ O Estaleiro Verolme, em Angra dos Reis, no Rio de Janeiro, historicamente um dos maiores do país, nesta época também paralisa suas atividades.
} 
Anterior à derrocada do Estaleiro Só com o encerramento em definitivo de suas atividades, o agravamento da crise era evidenciada pela mudança nas práticas de trabalho operário naval quando o Estaleiro, na ausência de novas encomendas de embarcações, passa a sucatear navios para venda de chapas de aço para siderúrgicas.

Seu Fernando, aposentado há dois anos, é chamado para trabalhar para atuar na área de segurança do trabalho. Se a prática de trabalho naval era de significativo risco aos operários, o sucateamento das suas peças se apresentava como inviável.

Eu fiquei em casa dois anos parado, ai o Estaleiro, a Gerdau encampou o Estaleiro para desmonte de navio. Ouviu falar disso ai? Ai estava morrendo um homem por mês de acidente. Eles cortavam os bloco, deixavam engaiolado, aquela coisa toda e o bloco caia e matava a pessoa. [...] Os cara se apavoraram... E eu fui sempre, o pessoal gostava muito de mim por que ........] fui um cara sempre positivo, correto, em termos de segurança, eu zelava muito isso ai. Então, me chamaram. Ai fiquei dois anos parado e ai fiquei mais três anos.

É interessante observar que para as reflexões que propostas privilegio os aposentados do Estaleiro cujas narrativas reordenam o passado no tempo presente e ritmam as suas trajetórias de trabalho em temporalidades distintas. A questão geracional nessas narrativas provoca a pensar nos trabalhadores que iniciam sua trajetória de trabalho num tempo de crise e, assim, a reordenam como tempo de trabalho.

A própria experiência de trabalho dos filhos de Seu Paulino e de Seu Fernando no Estaleiro é reveladora nesse sentido. O filho do Seu Paulino realiza os cursos de formação no Estaleiro, adquire experiência e hoje exerce a mesma função técnica em outra empresa. O filho de Seu Fernando se especializa na prática empreendida por ele no Estaleiro, segurança do trabalho.

Essa descontinuidade pensada na relação do passado diferencialmente ritmado por eles num tempo de trabalho e num tempo de crise não engendra apenas algo que terminou, mas o que pode vir. Alguns deles, como Seu Paulino, reencontram e reatualizam os antigos traços de um tempo de trabalho na retomada da construção naval, no estado do Rio Grande do Sul, na cidade de Rio Grande.

O cenário atual do setor de construção naval, no país, ${ }^{8}$ de incentivos governamentais para crescimento da indústria naval, muda o contexto de crise, nacionalmente e no estado do Rio Grande do Sul.

\footnotetext{
${ }^{8}$ Com base nos dados do Sindicato Nacional da Indústria da Construção e Reparação Naval e Offshore (SINAVAL), o Brasil reaparece nas estatísticas internacionais da construção naval e hoje ocupa a quinta posição no volume de encomendas. A expectativa é de maior crescimento com o pré-sal para o qual se entende que o parque naval brasileiro não está preparado. (Valor , 2011).
} 
Situada num contexto mais amplo de transformações recentes no cenário político e econômico nacional que colocaram a indústria naval novamente no cenário mundial, esta 'retomada' é trazida por ele como uma forma de reencontro com seu tempo de trabalho no Estaleiro,

Agora ta tudo em Rio Grande. Eu ainda tenho vontade. Se eu fosse mais novo ia fazer uma ficha no Estaleiro lá de Rio Grande, sim ganharam o Estaleiro, agora esses tempos eles tavam procurando gente para administração lá no Estaleiro. Eu tive lá esses tempos... [...]

(Seu Paulino)

Nas entrevistas, se, por um lado, o novo pólo de Rio Grande rompe com o 'desaparecimento' da prática antes exercida por esses trabalhadores, no estado, por outro, traz a ausência materializada nas ruínas do Estaleiro Só, no Pontal e pelos novos projetos urbanos previstos para aquela área.

Seu Paulino se recente daquele espaço de referência simbólica de sua trajetória de trabalho não ter se transformado numa nova 'fábrica', como dizia, engendrando a continuidade da prática de trabalho operário no Pontal.

O imaginar o Estaleiro, operando novamente, no Pontal, onde, até então, permaneciam suas ruínas, está presente nas narrativas dos antigos trabalhadores entrevistados. Seu Manoel fala das transformações recentes do Cristal e diz,

Uma vida.... Até hoje eu tenho saudade daquilo ali. Já pensou aquele shopping ali, aquele Estaleiro funcionando que movimento aquilo ali né tchê... era movimento, sem tamanho filha, coisa muito linda.

(Seu Manoel)

\section{E o destino do Pontal do Estaleiro?}

O 'Pontal do Estaleiro' enquanto espaço de trabalho operário desses antigos trabalhadores evoca a contraditória relação de presença e ausência de referências simbólicas das suas práticas de trabalho de construção naval na cidade de Porto Alegre, reificadas pelas ruínas do Estaleiro Só ali presentes ao longo de anos.

A rítmica de ocupação e transformação dos espaços da orla do Guaíba, acessados pela via das narrativas desses trabalhadores, revelam que a destruição das ruínas do Estaleiro Só representou o desaparecimento do espaço real sobre o qual eles referenciavam as temporalidades diferenciais de um tempo vivido de trabalho e de crise. 
Para alguns, como Seu Manoel, as memórias afetivas desse tempo de trabalho foram intensamente experienciadas na ruptura simbólica representada pela destruição das ruínas, marca física daquele espaço fabril e operário.

Eu vou te dizer assim, eu até me senti mal quando eu passei ali que vi que, por que eu tava na praia e quando eu fui pra praia tava tudo, prédio levantado ainda, as caldeira ali, a estrutural, tudo de pé, de repente eu passei ali e passaram a máquina e derrubaram tudo. Barbaridade. Senti foi um troço ruim, barbaridade, me deu assim uma tremura [...]. Mas, até hoje passo ali e chega me arrepiar o tempo que a gente passou ali. Agora vejo como ta ali ... barbaridade. Coisa de louco...

A transformação da área antes usada pelo antigo Estaleiro Só prevê um empreendimento imobiliário que teve a sua construção permitida através da alteração do Plano Diretor da cidade. Pela via de lógicas ideologizadas de valorização dessa área, pautadas em políticas públicas marcadas por um ideal progressista e de modernização (Eckert; Rocha, 2007), objetiva-se construir altos prédios comerciais, píer, bares, restaurantes, área de lazer, dentre outras intervenções.

A transferência da área do Pontal está sendo questionada judicialmente e, por enquanto, o projeto não se efetivou. Atualmente, a área serve de "canteiro de obras" do Projeto Integrado Socioambiental referido anteriormente, onde estão sendo armazenadas as tubulações dos emissários subaquáticos pelo órgão municipal de águas e esgotos.

As narrativas dos antigos trabalhadores do Estaleiro retraçam o passado e nos revelam um tempo de trabalho que permite pensar esse lugar no qual se pretendem essas significativas transformações, na Orla, desde outro ponto de vista.

Desafia pensar em que medida o espaço fabril e operário do Estaleiro, hoje "apagado" no gesto simbólico de destruição das suas ruínas, é revisto por um processo de "glorificação" em que esse mesmo espaço requalificado passa a ser território de consumo urbano segundo o projeto urbanístico previsto.

São as feições do tempo no arranjo das formas da vida social (Simmel, 2004) expressas nas continuidades e descontinuidades de um tempo vivido, descoberto pelas narrativas desses antigos trabalhadores e sua relação espaço-temporal com a conformação e dinâmica de transformação da região do Cristal e da Orla do Guaíba, que propiciam refletir sobre esse 'apagamento' de uma memória do trabalho na cidade de Porto Alegre. 


\section{Referências}

CALDEIRA, T.P. do R. Cidade de muros. São Paulo: Ed. Edusp, 2000.

ECKERT, Cornelia. Memória e Identidade. Ritmos e Ressonâncias da duração de uma comunidade de trabalho: mineiros de carvão (La Grand-Combe, França). Cadernos de Antropologia, n. 11. Porto Alegre: PPGAS/UFRGS, 1993.

ECKERT, C. "Questões em torno do uso de relatos e narrativas biográficas na experiência etnográfica". In: Humanas. Revista do Instituto de Filosofia e Ciências Humanas, v. 16, n.1. Porto Alegre: UFRGS, 1996/1997. p. 21-44.

ECKERT, Cornelia; ROCHA, Ana Luiza Carvalho da. "Etnografia da duração: estudos de memória coletiva". In: LOPES, Cícero Galleano; et.al. (Org.). Memória e cultura: perspectivas transdisciplinares. Canoas: La Salle, 2009.

ECKERT, Cornelia; ROCHA, Ana Luiza Carvalho da. "Narrar a cidade: experiências de etnografia da duração". In: Leituras da Cidade. POSSAMAI, Rita. (Org.). Porto Alegre: Evangraf, 2010. p. 85- 108.

JESUS, Claudiana Guedes; GITAHY, Leda. "Transformações na Indústria da Construção Naval Brasileira e seus Impactos no Mercado de Trabalho (1997-2007)". In: Anais do $1^{\circ}$ Congresso de Desenvolvimento Regional de Cabo Verde. Cabo Verde: APDR, 2009. p. 3898-3916.

LEITE LOPES, José Sergio. O vapor do diabo. O trabalho dos operários do açúcar. Rio de Janeiro: Paz e Terra, 1978.

PORTO ALEGRE. Prefeitura Municipal. Secretaria Municipal de cultura. Cristal. Porto Alegre: Unidade Editorial da Secretaria Municipal de cultura, 2003.

RETOMADA da indústria naval tem 269 projetos. Revista Valor Econômico, Rio de Janeiro, 21 de junho de 2011.

SIMMEL, G. Philosophie de la Modernité. Paris: Payot, 2004.

SETOR Naval. A todo vapor. Folha de São Paulo, São Paulo, 29 de maio de 2011.

SÓ Notícias. Ano 2- Número 3, Porto Alegre, novembro de 1976.

VELHO, G. Individualismo e Cultura. Notas para uma antropologia da sociedade contemporânea. Rio de Janeiro: Jorge Zahar, 2004.

VELHO, G. (Org.). Rio de Janeiro: cultura, política e conflito. Rio de Janeiro: Zahar, 2007. p. 7-29.

Recebido em: 22/05/2012

Aprovado em: 02/07/2012 